\title{
The Effect of Sukuk Ijarah Issuance on Company Profitability in Indonesia
}

\author{
Muhammad Suhaidi ${ }^{1}$, Mardhiyah Hayati ${ }^{2}$ \\ \{muhammadsuhaidi545@gmail.com ${ }^{1}$, mardiyah.hayati@ radenintan.ac.id² \\ Graduate Program of Raden Intan Lampung Islamic State University, Indonesia ${ }^{1}$, Raden \\ Intan Lampung State Islamic State University, Indonesia ${ }^{2}$
}

\begin{abstract}
The issuance of corporate securities can increase the profitability ratio. One of the securities that can be issued is the ijarah sukuk, securities issued on the basis of Islamic values and considered quite prospective for the issuer. In Indonesia, ijarah sukuk is issued by various companies, hence this research was carried out to know the reason and to find the relationship with the company profitability. The population in this study were all companies that issued ijarah sukuk on the Indonesia Stock Exchange (IDX) from 2013 to 2018. The sampling technique was purposive which indicated that only 9 companies met the criteria. The results showed that the ijarah sukuk had an influence on the company's profitability. When the ratio of the ijarah sukuk increases by $1 \%$, the profitability increases by $0.393 \%$.
\end{abstract}

Keywords: Ijarah Sukuk, Profitability.

\section{Introduction}

The business climate is growing according to the trends [1]. The development is caused by various human activities that continue to increase. Thus, a business certainly has various objectives, one of which is to achieve a certain level of profit or even more. In order for to achieve these goals, the company's operations must be smooth and be able to take advantage of all available resources. This is done in order to achieve optimal profit and can affect the survival of the community.

In companies, profit or profitability can be interpreted as a prospect for the future or as a potentially good development for the company. Thus, how the company performs is very important for assessing various potential changes. This is done to assess potential changes in economic resources that is potential to be controlled in the future. In addition, it can be used to predict the production capacity of the existing resources. This means that the company's financial statements must be analyzed thereby it can be used by the company leaders as a decision-making tool and used by the shareholders to see the financial performance [2].

Good company performance reflected in the financial statements is part of the company's excellence [3]. It can be implied that the measurement of company performance, one of which is the profitability ratio because it enables to see the effectiveness of a company. Thus, the companies are required to make efforts to obtain maximum profit. One of the ways that a company can do to obtain maximum profit is by increasing the company's capital such as issuing securities [4]. 
The issuance of corporate securities can increase the profitability ratio [5]. It is because how the way a company can increase capital for its operations which in turn will affect profits. However, securities have various types even in the growing Islamic financial system and Islamic business, many companies issue securities based on Islamic values.

In Indonesia, one of these securities is in the form of Ijarah sukuk [4]. Ijarah Sukuk in the fatwa of the National Sharia Council (Indonesia) Number 41 / DSN-MUI / III / 2004 states that ijarah sukuk is a securities based on an ijarah agreement or contract with the scheme of renting out the benefits of an asset to another party based on the agreed price and period without transfer of title.

The ijarah sukuk is considered quite prospective for issuers [6]. The issuance of ijarah sukuk itself has a function as a financing instrument as well as an investment instrument offered in various forms or various sharia contract structures. In Islamic economics, investment in ijarah sukuk is an investment that is recommended because it prioritizes Islamic law and is based on the economic foundations that are permitted in Islamic laws. In addition, this type of investment, ijarah sukuk, is an investment that is not only for Muslims but also is for various investors from different religious backgrounds [7].

This situation shows that the ijarah sukuk is considered capable of influencing the company's profitability [8]. Moreover, the ijarah sukuk is also considered to be one of the instruments that capable of making profitability increase significantly with good company management. In order to know the proportion of the financing use through sukuk, it is calculated by the proxy ratio, namely the Sukuk to Equity Ratio. This ratio will measure the proxies of funds originating from sukuk in the company's equity.

In Indonesia, there are 9 companies that have issued ijarah sukuk, as shown in the following table:

Table 1

The Development of Sukuk to Equity Ratio

\begin{tabular}{|c|c|c|c|c|c|c|c|c|}
\hline \multirow[t]{2}{*}{ No } & \multirow[t]{2}{*}{ Company name } & \multicolumn{7}{|c|}{ Years } \\
\hline & & 2013 & 2014 & 2015 & 2016 & 2017 & 2018 & Average \\
\hline 1 & $\begin{array}{l}\text { PT Aneka Gas Industri } \\
\text { Tbk }\end{array}$ & 0.06 & 0.04 & 0.02 & 0.02 & 0.01 & 0.01 & 0.03 \\
\hline 2 & $\begin{array}{l}\text { PT Sumberdaya } \\
\text { Sewatama Tbk }\end{array}$ & 0.04 & 0.07 & 0.04 & 0.38 & 0.37 & 0.35 & 0.21 \\
\hline 3 & PT Indosat Tbk & 0.47 & 0.59 & 0.48 & 0.41 & 0.46 & 0.58 & 0.50 \\
\hline 4 & $\begin{array}{l}\text { PT Perusahaan Listrik } \\
\text { Negara (Persero) Tbk }\end{array}$ & 0.09 & 0.19 & 0.02 & 0.02 & 0.03 & 0.01 & 0.06 \\
\hline 5 & $\begin{array}{l}\text { PT Mitra Adiperkasa } \\
\text { Tbk }\end{array}$ & 0.07 & 0.02 & 0.01 & 0.01 & 0.01 & 0.01 & 0.02 \\
\hline 6 & $\begin{array}{l}\text { PT Pupuk Kalimantan } \\
\text { Timur Tbk }\end{array}$ & 0.01 & 0.01 & 0.01 & 0.32 & 0.28 & 0.29 & 0.15 \\
\hline 7 & $\begin{array}{l}\text { PT Salim Ivomas } \\
\text { Pratama Tbk }\end{array}$ & 0.01 & 0.02 & 0.01 & 0.01 & 0.01 & 0.01 & 0.01 \\
\hline 8 & $\begin{array}{l}\text { PT Berlian Laju Tanker } \\
\text { Tbk }\end{array}$ & 0.06 & 0.04 & 0.18 & 0.09 & 0.17 & 0.15 & 0.12 \\
\hline 9 & $\begin{array}{l}\text { PT Summercon Agung } \\
\text { Tbk }\end{array}$ & 0.04 & 0.01 & 0.01 & 0.01 & 0.01 & 0.02 & 0.02 \\
\hline
\end{tabular}

Source: Indonesia Stock Exchange 
Table number 1 shows how the development of the sukuk to equity ratio from 2013-2018. The table shows that Indosat Tbk company occupies the highest position in its development ratio. This shows that the company gets a better source of funding from the ijarah sukuk than other companies and more people who buy to own sukuk of the company than to invest in other companies. However, can it be justified if the issuance of ijarah sukuk is able to affect the company's profitability? Moreover, there are many other instruments that a company can issue and the growth of ijarah sukuk in other companies tends to be small, hence, the effect needs to be examined further. In fact, with further observation, almost all companies did not experience growth of more than $1 \%$.

\section{Literature Review}

The term 'Investment' means something different to economists than it does to most of the rest of the world. Sukuk is not a new term in Islamic history because it has been known since the Middle Ages, when Muslims used it in the context of international trade. Sukuk is the plural form of the word shakk [9]. It was used by traders at that time as a document showing financial obligations arising from trading businesses and other commercial activities. However, a number of Western writers who are concerned with the history of Islam and the Arab nation, state that this shakk is the root of the word "check" in Latin, which is now commonly used in contemporary banking transactions [9].

Terminologically, shakk is a paper or note on which there is an order from someone to pay a certain amount of money to another person whose name is written on the paper. In short, the Accounting and Auditing Organization for Islamic Financial Institutions (AAOFI) defines sukuk as a certificate of equal value which is evidence of ownership distributed over an asset, benefit rights and services or ownership of certain investment projects or activities.

Specifically, ijarah sukuk is a sukuk issued based on an agreement or ijarah contract where one party acts himself or through a representative sells or leases the beneficial rights of an asset to another party based on the agreed price and period, without being followed by a transfer of ownership of the asset itself.

Another definition of ijarah sukuk is financing using the ijarah contract system, or securities containing financing contracts based on sharia principles issued by companies, governments or other institutions that require the issuer to pay income to sukuk holders in the form of fees from the proceeds of leasing assets and repaying the principal funds of the sukuk at due date [10].

Profitability refers to a ratio used to measure a company's ability to generate profits from its normal business activities. The profitability ratio is also known as the reliability ratio. Besides aiming to determine the company's ability to generate profits over a certain period, this ratio also aims to measure the level of management effectiveness in carrying out company operations. The profitability ratio is the ratio that describes the company's ability to generate profits through all its capabilities and resources, namely those derived from sales activities, use of assets, and use of capital. The profitability ratio or rent-ability ratio can be used as a tool to measure the level of performance effectiveness of finance [11]. 


\section{Methods}

The method used in this research is associative quantitative research using secondary data obtained from the Indonesia Stock Exchange (IDX) 2013-2018. The population of this study were 18 companies that issued Ijarah sukuk on IDX from 2013-2018. While the sampling used purposive sampling hence only 9 companies meet the criteria. Tests conducted in the study used computer-based statistical tools with regression.

\section{Result and Discussion}

The results showed that the ijarah sukuk issued by companies in Indonesia had an influence on the company's profitability. The effect of Sukuk to Equity Ratio on company's profitability has a continuous effect. This shows that the Sukuk to Equity Ratio is the underlying profitability. The effect of Sukuk to Equity Ratio on profitability shows that the greater this influence, the better the company's ability to pay Sukuk so that it can also attract investors to invest their capital, but usually investors tend to see the profitability of a company first.

Investment through ijarah sukuk is an investment that is recommended both in Islamic and conventional law considering that it has criteria that do not violate the law and are disgusting to either Muslims or non-Muslims. In Islamic economics there are several investment criteria that are taught, among others, the company must be clear, the halal product and the process. Therefore, investing through ijarah sukuk can be an alternative as well as a solution for investors in investing. Regarding the majority of Muslims in Indonesia, it will certainly be a strategic market share for investors and companies.

The results of the analysis indicated that the effect of Sukuk To Equity Ratio has a significant effect on company profitability. When ijarah sukuk increases by $1 \%$ it will affect a $0.393 \%$ increase in the company's profitability and score $t_{\text {count }}>t_{\text {table }}(2,996>2,0167)$. This is because the high value of the sukuk to equity ratio can increase investors' interest in investing in the sukuk issuer. In addition to increasing investors, a high sukuk to equity ratio can also increase the profitability of a company because in the Islamic economy the value of sukuk to equity ratio is the underlying value of profitability.

\section{Conclusion}

As informed previously, every investor is expected to have the advantage of investing, investing in sukuk ijarah can be an option. People can buy ijarah sukuk from the primary market and ijarah sukuk can also be sold on the secondary market. This means that the sukuk that investors have purchased can be resold when the market price is higher than the purchase price. If the sukuk has been sold before the contract time, the sukuk has been sold on the secondary market, investors will get a margin from the remaining years before the due date. Then, the first party who has sold the sukuk will not get a margin from the sukuk, because it has changed owners. 


\section{References}

[1] G. Raketteye, "Global Trends and Their Influence on Future Busines Performance," Int. J. Bus. Perform. Manag., vol. 14, no. 1, pp. 95-110, 2013.

[2] Barkian, Analisis Laporan Keuangan: Teori dan Praktik. Jakarta: Bumi Aksara, 2009.

[3] R. Gupta, "Business Excelence Measures and Prediction of Financial Performance - A Study of Selected Listed Companies in India," Sobhagya Consult. Mark. Serv. India, vol. 1, no. 1, 2013.

[4] Hery, Analisis Laporan Keuangan: Integrated And Comprehensive Edition. Jakarta: PT. Gramedia Widasarana Indonesia, 2016.

[5] R. Moch, "The Effect of Liquidity, Profitability, and Solvability to the Financial Distres of Manufactured Companies Listed on The Indonesia Stock Exchange (IDX) Period Year 20152017," Acad. Account. Financ. Stud. J., vol. 23, no. 6, pp. 1-16, 2019.

[6] Yuliana, "Pengaruh Kinerja keuangan Terhadap Penetapan Tingkat Sewa Obligasi Syariah Ijarah di Indonesia," J. Ekon. dan Manaj., vol. 6, no. 1, pp. 219-250, 2010.

[7] A. Rahman, "Impact of Time Value of Money Theory in Ijarah Sukuk Genuineness: the Case of Bahrain and Malaysia," Int. Bus. Res., vol. 11, no. 7, pp. 56-62, 2018.

[8] M. Hanafi, "Pengaruh penerbitan sukuk ijarah terhadap profitabilitas perusahaan yang terdaftar di bursa efek Indonesia tahun,” J. Erat Acitya - UNTAG, vol. 4, no. 3, pp. 70-85, 2015.

[9] A. Fatah, "Perkembangan Obligasi Syariah (Sukuk) di Indonesia: Peluang dan Tantangan," J. Al-'Adalah, vol. X, no. 1, pp. 36-43, 2011.

[10] Ryandono, Bursa Efek Dan Investasi Syariah. Jakarta: Serambi, 2009.

[11] M. Hariyanto, Analisis Laporan Keuangan Integrated And Comprehensive Edition. Jakarta: PT. Gramedia Widasarana Indonesia, 2014. 